\title{
Feeding preference of recaptured Atlantic salmon Salmo salar following simulated escape from fish pens during autumn
}

\author{
R. E. Olsen ${ }^{1, *}$, O. T. Skilbrei ${ }^{2}$ \\ ${ }^{1}$ Institute of Marine Research, Matre Research Station, 5984 Matredal, Norway \\ ${ }^{2}$ Institute of Marine Research, PO Box 1870 Nordnes, 5817 Bergen, Norway
}

\begin{abstract}
Escapes of farmed fish from coastal farms around the world are believed to have genetic and ecological consequences for wild fish populations. Each year there are numerous escapes of adult farmed Atlantic salmon Salmo salar. However, survival until maturity appears to be low. One possible explanation is that many of these salmon have difficulties switching to live prey. To address this possibility, growth rate and dietary preference were recorded in recaptured salmon released in 3 groups from August to October 2008 within a small fjord in south-western Norway (Masfjord). The fish were primed with a commercial diet containing $11 \%$ of the 'vegetable oil marker' 18:2n-6 before release. In the 14.5 to $35.1 \%$ of fish recaptured, growth rates were generally good $\left(0.21-1.23 \% \mathrm{~d}^{-1}\right.$ of fish recaptured in main fjord $>2$ mo after release), with body weight doubled or more for fish recaptured after 19 wk and thereafter. However, fish recaptured in a small arm of Masfjord (Hopsvåg) had a growth rate close to zero and were in poor condition. While stomachs of recaptured fish were generally empty in the first weeks after release, pellets from fish farms were found in more than $80 \%$ of the stomachs after $12 \mathrm{wk}$ and thereafter. Additionally, the level of 18:2n-6 in depot lipids (11\% of fatty acids) of the muscle indicated that none of the fish recaptured the following autumn and winter in the vicinity of the release site had switched to wild prey diets. Salmon that escape during autumn are unlikely to compete for prey with wild fish in the vicinity of the release site.
\end{abstract}

KEY WORDS: Escaped farmed salmon $\cdot$ Behavior $\cdot$ Feeding preference $\cdot$ Triacylglycerols $\cdot$ Fatty acid composition · Survival

Resale or republication not permitted without written consent of the publisher

\section{INTRODUCTION}

Following the rapid expansion in farming of Atlantic salmon since the mid-1960s, escapes from cages has become a serious problem both for the fish farming industry and for the conservation of wild stocks. One of the more serious challenges is that farming has been correlated with declines in natural salmon populations (Ford \& Myers 2008). Escapees will interfere with the genetic make-up of wild stocks if they manage to interbreed and may potentially contribute to the spread of diseases and parasites (Lura \& Sægrov 1991, Heuch \& Mo 2001, McGinnity et al. 2004, Naylor et al. 2005, Hindar et al. 2006, Skaala et al. 2006, Ferguson et al. 2007, Fraser et al. 2010, Skilbrei et al. 2010).
The official figures of salmon escapees from fish farms in Norway has varied from below 200000 to 900000 during the period from 2001 to 2009 (Jensen et al. 2010). However, the actual number is probably much higher (Baarøy et al. 2004, Skilbrei \& Wennevik 2006). The estimated total catch of farmed fish in salmon rivers throughout Norway is below 10000, which is low compared to the total reported escapees (Anon 2010). In accordance with this, high recaptures of tagged adult salmon have been reported in the vicinity of release sites for the first months after release, but none or very few have been found in freshwater (Hansen 2006, Skilbrei \& Jørgensen 2010, Skilbrei et al. 2010). It therefore appears that survival until fish mature and enter rivers is low. Little is however 
known about the general performance and causes of mortality of fish after they escape. Hansen (2006) found that fish escaping during autumn and winter migrate to open sea but do not survive the cold winter. Fish may also have a problem switching to live prey, possibly depending on their age, life stage, time spent in cages and species. Some indications of the latter were given in a Chilean study where escaped coho salmon Oncorhynchus kisutch and rainbow trout $O$. mykiss appeared to switch readily to natural prey diets, while escaped Atlantic salmon had the highest level of stomach emptiness and the highest occurrence of pellets from fish farms in their stomachs (Soto et al. 2001). However, the fish were of unknown origin, so the contribution of feed pellets on subsequent growth could not be estimated. There are, to our knowledge, no detailed studies of feeding behavior of newly escaped adult salmon in fjord and coastal areas.

The aim of the current experiment was therefore to study growth and feeding preference of escaped Atlantic salmon. The target area chosen was Masfjorden, Western Norway. This is a well controlled area with respect to fish farming activity and fishing efforts, and where migratory behavior of released farmed fish is well documented (Skilbrei 2010).

\section{MATERIALS AND METHODS}

Fish, tagging and diet. The fish were of the domesticated Aqua Gen strain that is widely used in Norwegian fish farming. They were produced at the hatchery at Matre Research Station, Institute of Marine Research (IMR), Matre, Western Norway. One-year old smolts were transferred to sea cages close to the Research Station, in the inner Masfjord, used for further rearing and releases (see Fig. 1). Release groups were produced by tagging 1780 to 3700 fish with T-bar anchor tags (Hallprint). The first tagging was done in the hatchery on May 9, 2008 when the fish were still in freshwater, 2 days prior to transfer to seawater. The next groups were tagged with 5 to $7 \mathrm{wk}$ intervals from June 20 to October 21, 2008 in the sea cage facility, and 6 to $8 \mathrm{~d}$ before release (Table 1). Fork length of all fish and weight of samples were recorded. In addition, a small number of salmon were equipped with $9 \mathrm{~mm}$ telemetry transmitters for studies of migratory behavior (Skilbrei 2010).

To enable a distinction of feed preference, the fish were primed with a commercial diet containing vegetable lipid sufficient to give a relatively high level of the 'plant' fatty acid linoleic acid (18:2n-6) which is found in only minute amounts in natural prey. This particular diet also had elevated contents of 18:1n-9, suggesting that canola oil is a major ingredient in the diet preparations. Other dominant fatty acids were 16:0 (12.7\%) and with a good balance of 20:5n-3 and $22: 6 n-3$ at around $6 \%$ each. As the fatty acid composition, in depot lipids in particular, is governed by that of the diet (Henderson \& Tocher 1987, Torstensen et al. 2005), any change in 18:2n-6, and other fatty acids, can be used an indicator of prey preference. The method has previously been shown to be well suited for distinguishing between escaped and wild salmon (Megdal et al. 2009), and assessing the impact of fish farming on marine fish composition (Skog et al. 2003, FernandezJover et al. 2007).

Recapture of tagged fish. The letters HI (Norwegian acronym for the IMR), the IMR internet address (www. imr.no) and postal code were printed on the T-bar tags in addition to an individual alphanumeric code. The reward was 100 NOK per T-bar anchor tag returned. T-bar anchor tags were returned by fishers after capture by rod or gill-net in the inner and middle part of the fjord. More than $90 \%$ of the fish caught by rod were angled in the vicinity of the 2 fish farms or in the effluent water from a hydropower plant that attracts escaped farmed salmon and is a popular site for anglers. All gill-netted salmon were caught in the inner part of the fjord (between Solheim and Matre, Fig. 1). Of these, $85 \%$ were provided by a single fisherman who was the only professional fisher in the fjord. The fisher used mainly 60 to $63 \mathrm{~mm}$ mesh-sized nets gill-nets and fished regularly during autumn, except for the first $3 \mathrm{wk}$ of December. He was also engaged by the project to recapture fish on a daily basis from late December onwards, and delivered 141 fish for inspection of stomach content. The fish used for analysis of fatty acids were chosen from the gill-net catches of this fisher during the period November 8, 2008 to April 1, 2009. A detailed description of the recaptures of both T-bar tagged fish and fish equipped with telemetry transmitters is given in Skilbrei (2010).

Student's $t$-test was applied to compare the specific growth rate $\left(\mathrm{SGR}, \% \mathrm{~d}^{-1}\right)$ and sizes of the fish recaptured in Masfjord with those recaptured in a small arm of the fjord. Specific growth rate was calculated from the formula SGR $=100 \times\left[\ln \left(W_{2}\right)-\ln \left(W_{1}\right)\right] /\left(t_{2}-t_{1}\right)$, where $W_{2}$ and $W_{1}$ are the weights $(\mathrm{g})$ of the individual at Day $t_{2}$ and $t_{1}$, respectively. For fish that were only measured for length $(\mathrm{cm})$ at tagging $\left(L_{1}\right)$, the weight $\left(W_{1}\right)$ was estimated by rearranging the formula for condition factor, $\mathrm{C}_{1}=100 \times W_{1} L_{1}^{-3}$ ) where $\mathrm{C}_{1}$ was the mean condition factor of the group.

Sampling of wild fish. To obtain an estimate of wild fish and wild prey fatty acid composition in Masfjord, 10 brown trout Salmo trutta and 1 cod Gadus morhua were captured using gill-nets in April in the area where most escaped Atlantic salmons were caught. Of 
Table 1. Salmo salar. Numbers of Atlantic salmon, tagging and release dates in 2008, mean $( \pm$ SD) weight at tagging and recapture (after $>2$ to $8 \mathrm{mo}$ ), and recapture rates (\%) of each release group in Masfjord

\begin{tabular}{|c|c|c|c|c|c|c|}
\hline \multirow{2}{*}{ Release group } & \multirow[t]{2}{*}{$\mathrm{n}$} & \multirow{2}{*}{ Tagging date } & \multirow{2}{*}{ Release date } & \multicolumn{2}{|c|}{$\longrightarrow$ Weight $(\mathrm{kg})-$} & \multirow{2}{*}{$\begin{array}{c}\text { No. recaptured } \\
(\%)\end{array}$} \\
\hline & & & & At release & At recapture & \\
\hline May & 3700 & 7-8 May & 16 May & $0.15 \pm 0.04$ & - & $0(0)$ \\
\hline June & 2000 & 18 Jun & 26 Jun & $0.19 \pm 0.05$ & $0.83 \pm 0.10$ & $3(0.2)$ \\
\hline August & 2000 & 6 Aug & 14 Aug & $0.45 \pm 0.14$ & $2.06 \pm 1.25$ & $290(14.5)$ \\
\hline September & 2000 & $10 \mathrm{Sep}$ & $17 \mathrm{Sep}$ & $0.87 \pm 0.26$ & $2.93 \pm 1.09$ & $702(35.1)$ \\
\hline October & 1780 & 20 Oct & 27 Oct & $1.30 \pm 0.34$ & $2.97 \pm 0.90$ & $520(29.2)$ \\
\hline
\end{tabular}

these, 8 trouts had guts filled with prey and was processed further. Two were empty and subsequently excluded. The focus on brown trout was mainly because wild Atlantic salmon is absent in the fjord during winter. Being the closest relative to salmon, they are likely to have similar feeding habits and prey preferences.

Lipid analysis. Muscle samples and gut contents from 8 brown trout, $1 \mathrm{cod}$, and 38 randomly selected Atlantic salmon released in October representing the whole period of recapture, including 5 individuals from Hopsvåg belonging to this release group, were collected from semi-thawed fish and stored at $-80^{\circ} \mathrm{C}$ until further processing. Mean $\pm \mathrm{SD}$ length and weight of recaptured salmon were $57 \pm 6 \mathrm{~cm}$ and $2.5 \pm 0.9 \mathrm{~kg}$. In addition, 6 sea-ranched salmon of a mean weight of $5.4 \pm 1.3 \mathrm{~kg}$ that were recaptured in Matre in 2010 were analyzed. These fish were tagged and released from Matre in 2007 (3 fish), 2008 (2 fish) and 2009 (1 fish). Total lipids were extracted using the method

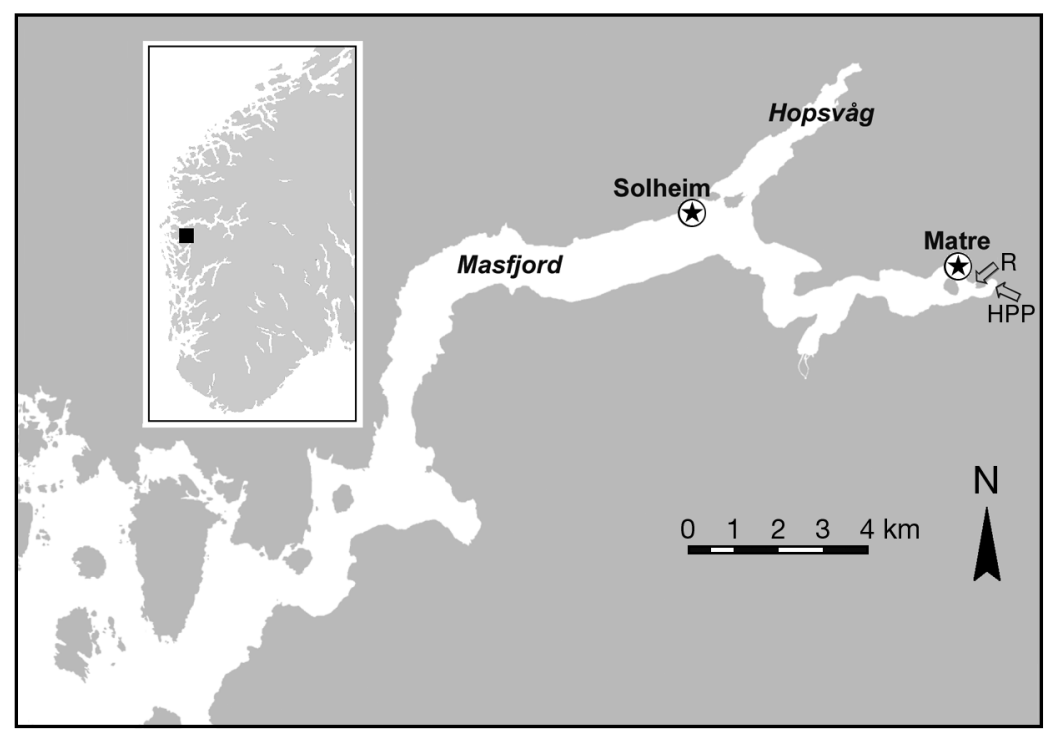

Fig. 1. Location in the inner part of Masfjord, Norway, of the fish farms at Matre (release site) and Solheim $(\circledast)$, the Matre River $(\mathrm{R})$, the hydropower plant (HPP) (arrows), and the fjord arm Hopsvåg of Folch et al. (1957). Depot lipids, triacylglycerols (TAG), were separated using $10 \times 10 \mathrm{~cm}$ HPTLC plates (Merck) using the neutral solvent system of Olsen \& Henderson (1989). The TAG was visualized using a $0.2 \% 2^{\prime}, 7^{\prime}$-dichlorofluorescin in $95 \%$ ethanol spray and viewed under UV-light for detection. The TAG fraction was then scraped off the plates and subjected to sulphuric acid-catalysed transesterification (Christie 1982), extracted into hexane and stored at $-80^{\circ} \mathrm{C}$ until analysed. Stomach lipids were not separated, but subjected to direct transmethylation (total lipid) according to the procedure above. Quantitative analysis of fatty acid methyl esters were carried out by gas liquid chromatography using a HP 5890 gas chromatograph equipped with a J\&N Scientific Inc DB-23 fused silica column (30 $\mathrm{m} \times 0.25 \mathrm{~mm}$ internal diameter). The oven temperature was programmed to rise from 50 to $170^{\circ} \mathrm{C}$ at $25^{\circ} \mathrm{C} \mathrm{min} \mathrm{m}^{-1}$, and then to $210^{\circ} \mathrm{C}$ at $1.5^{\circ} \mathrm{C} \mathrm{min}{ }^{-1}$ with a final holding time of $5 \mathrm{~min}$. Separated components were identified with reference to authentic standards (prepared on customer request, Nu-Chek Prep).

\section{RESULTS}

\section{Recapture and stomach content}

The percentages of recaptured fish and the timing of catches varied between the releases. A higher proportion of fish released in October remained in the area during winter (Fig. 2). The total recaptures of T-bar tagged fish in the fjord following the May, June, August, September and October releases were 0.0, 0.2, 14.5, 35.1 and $29.2 \%$ (corresponding to $\mathrm{n}=0,7,290,702$ and 520 fish), respectively. Skilbrei (2010) gives a more detailed description of the differences in catch with time of release, and telemetry data showing that the fish released in 


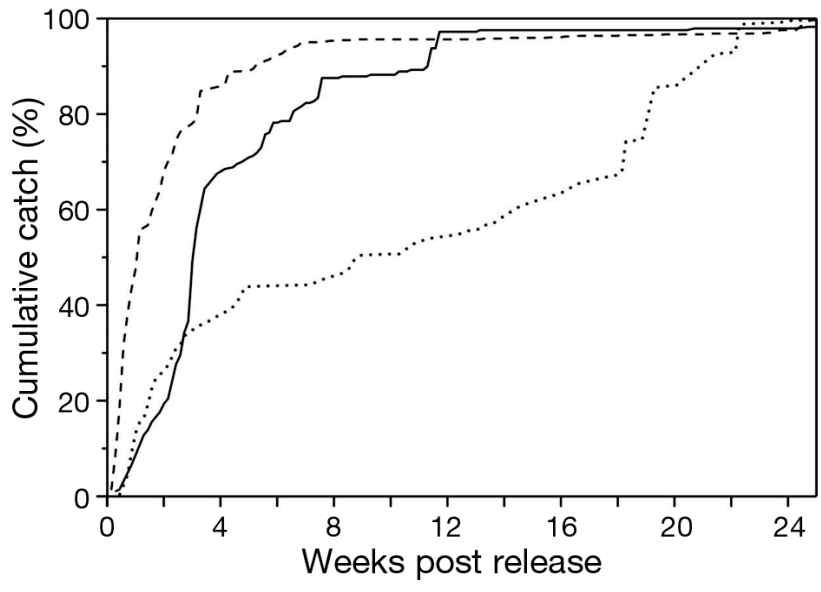

Fig. 2. Salmo salar. Cumulative catches in Masfjord following the August (solid line, $\mathrm{n}=290$ ), September (dashed line, $\mathrm{n}=$ 702 ) and October (dotted line, $n=520) 2008$ releases. Source: Skilbrei (2010)

May and June moved rapidly out of the fjord. Nineteen weeks after the releases, recaptured fish had grown to sizes 2 to 4 times their size at release (Fig. 3, Table 1). There were no further reports of recaptures in Masfjord, or elsewhere, until autumn 2010 when nine 2sea-winter salmon were recaptured at Matre. These fish originated from the first 4 releases (from May to September 2008). Two of them were used for analysis of fatty acid composition.

The stomachs of more than $80 \%$ of the fish recaptured during autumn 2008 were empty for the first weeks after release. The proportion of fish feeding on pellets increased with time. Eventually, 80 to $90 \%$ ate pellets 12 wk after release (Fig. 4). The natural food found in some stomachs consisted of a few fish alevins and small shrimps.

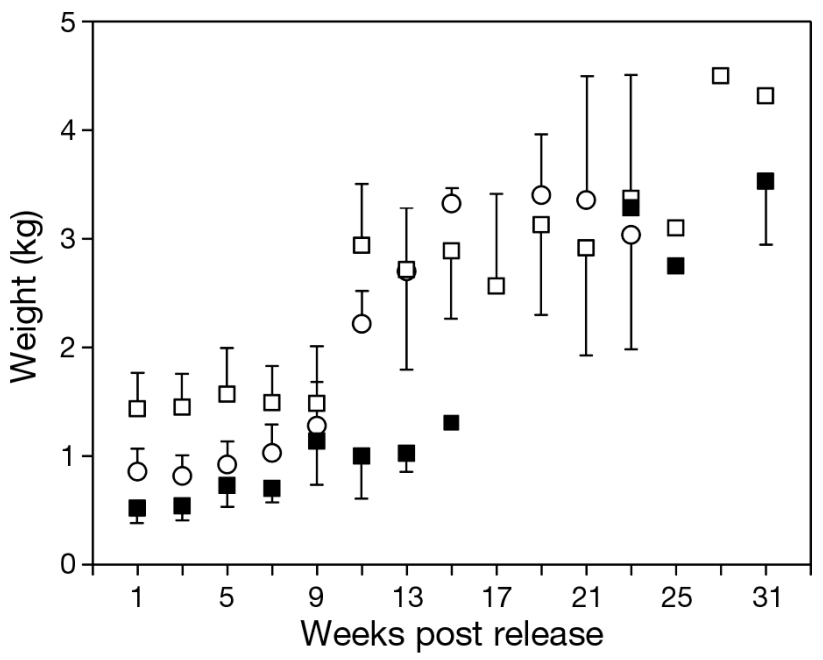

Fig. 3. Salmo salar. Mean (i.e. + or $-\mathrm{SD}$, where $\mathrm{n}>1$ ) weight of recaptured fish every second week after release on Aug 14 (ם), Sep 17 (O) or Oct 27 (口), 2008

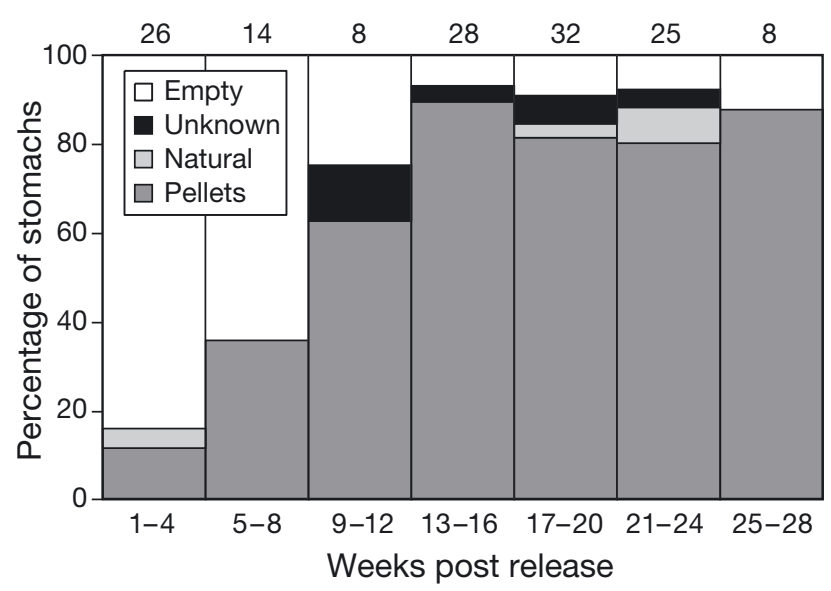

Fig. 4. Salmo salar. Stomach content in recaptured tagged Atlantic salmon versus the number of weeks post release. Percentage of fish in catch with empty stomachs, small and unknown content, natural food or pellets in stomach. Numbers of inspected stomachs during each 4 wk period are shown above the bars

\section{Fatty acid composition}

Brown trout, and salmon muscle and cod liver triacylglycerols composition along with diet composition offered to fish in sea-cages, and stomach contents of the selected brown trouts and cod is given in Table 2 as average values. Values of 18:2n-6 for each fish are plotted in Fig. 5. The level of 18:2n-6 in muscle TAG of recaptured Atlantic salmon was in the range of $11 \%$ for all fish, which was in the same range of that of the diet (Table 2, Fig. 5). The same was true for low condition index fish caught in Hopsvågen (Fig. 5). In general, these fish also had high levels of 18:1n-9, and rather similar to the commercial feed. Conversely, the 18:2n-6 content of muscle TAG in wild trout, and cod liver TAG was around $2 \%$, which was in the same range as that of their stomach contents. Other predominating fatty acids were 16:0, 16:1, 20:1n-9, 22:1n-11, 20:5n-3 and 22:6n-3 (Table 2). Gut contents of wild caught brown trout were only 1 to $1.5 \% 18: 2 n-6$. The fatty acid composition of other prey fatty acids varied highly, probably due to variability of the prey animal giving a relatively high standard deviation. However, most prey fatty acids were dominated by $16: 0,18: 1 n-9$, $20: 5 n-3$ and $22: 6 n-3$, that are typical of membrane phospholipids (Henderson \& Tocher 1987) indicating lean prey animals with little depot lipids. The cod stomach contents were similar to that of brown trout with low levels of 18:2n-6 and relatively high amounts of 16:0,18:1n-9, 20:5n-3 and 22:6n-3.

The 5 fish recaptured in Hopsvågen were of equal length at release $(46.2 \pm 1.6$ vs. $45.2 \pm 3.9 \mathrm{~cm})$ but grew significantly slower $\left(0.03 \pm 0.09\right.$ vs. $\left.0.57 \pm 0.02 \% \mathrm{~d}^{-1}\right)$, were significantly smaller when recaptured $(1.5 \pm 0.4$ 
Table 2. Fatty acid composition (\% of fatty acids) of stomach contents and commercial diet (total lipid fatty acid composition), and brown trout Salmo trutta and Atlantic salmon Salmo salar muscle and cod liver Gadus morhua triacylglycerol (TAG) fatty acid composition of selected fish analyzed in the present study. Salmon denoted 2008-9 represent fish recaptured during the first 23 wk post release, and salmon 2010 denotes fish captured during summer/autumn 2010. SAT: saturated fatty acids; MONO: monounsaturated fatty acids; PUFA: polyunsaturated fatty acids; n-3/n-6: ratio of n-6 PUFA to n-3 PUFA

\begin{tabular}{|c|c|c|c|c|c|c|c|}
\hline \multirow[t]{3}{*}{ Fatty acid } & \multicolumn{3}{|c|}{ Total lipids } & \multirow{3}{*}{$\begin{array}{l}\text { Muscle } \\
\text { Trout } \\
(\mathrm{n}=8)\end{array}$} & \multirow{3}{*}{$\begin{array}{l}\text { Dep } \\
\text { Liver } \\
\text { Cod } \\
(\mathrm{n}=1)\end{array}$} & \multirow{2}{*}{\multicolumn{2}{|c|}{ ipids (TAG)- }} \\
\hline & \multicolumn{2}{|c|}{- Stomach $\longleftarrow$} & \multirow{2}{*}{$\begin{array}{c}\text { Commercial } \\
\text { diet } \\
(\mathrm{n}=4)\end{array}$} & & & & \\
\hline & $\begin{array}{l}\text { Trout } \\
(\mathrm{n}=8)\end{array}$ & $\begin{array}{c}\text { Cod } \\
(n=1)\end{array}$ & & & & $\begin{array}{l}\text { Salmon 2008-9 } \\
\quad(\mathrm{n}=38)\end{array}$ & $\begin{array}{l}\text { Salmon } 2010 \\
\quad(\mathrm{n}=6)\end{array}$ \\
\hline $14: 0$ & $4.3 \pm 3.1$ & 3.1 & $3.8 \pm 0.1$ & $4.3 \pm 1.1$ & 3.7 & $3.8 \pm 0.3$ & $3.6 \pm 0.5$ \\
\hline $16: 0$ & $17.3 \pm 2.4$ & 18.9 & $12.7 \pm 0.3$ & $19.8 \pm 2.8$ & 17.8 & $12.2 \pm 0.8$ & $13.2 \pm 3.3$ \\
\hline $16: 1 \mathrm{n}-7$ & $3.9 \pm 1.9$ & 5.8 & $3.8 \pm 0.1$ & $7.9 \pm 1.2$ & 6.0 & $2.7 \pm 1.6$ & $5.2 \pm 0.6$ \\
\hline $18: 0$ & $3.2 \pm 1.7$ & 6.1 & $2.6 \pm 0.0$ & $4.8 \pm 0.7$ & 5.8 & $3.1 \pm 0.2$ & $2.7 \pm 0.6$ \\
\hline $18: 1 n-9$ & $10.4 \pm 1.3$ & 15.7 & $33.4 \pm 0.2$ & $23.8 \pm 4.0$ & 17.4 & $35.0 \pm 1.5$ & $20.4 \pm 2.5$ \\
\hline $18: 1 n-7$ & $2.3 \pm 0.6$ & 5.6 & $3.0 \pm 0.0$ & $3.7 \pm 0.7$ & 5.6 & $3.2 \pm 0.1$ & $4.0 \pm 0.9$ \\
\hline $18: 2 n-6$ & $1.4 \pm 0.3$ & 2.1 & $11.4 \pm 0.0$ & $2.1 \pm 0.9$ & 2.2 & $11.3 \pm 0.4$ & $1.6 \pm 0.3$ \\
\hline $20: 1 n-9$ & $5.5 \pm 3.9$ & 3.6 & $2.4 \pm 0.2$ & $5.7 \pm 1.6$ & 3.7 & $4.5 \pm 0.5$ & $13.1 \pm 5.1$ \\
\hline $20: 4 n-6$ & $1.0 \pm 0.7$ & 2.3 & $0.4 \pm 0.0$ & $0.6 \pm 0.1$ & 1.8 & $0.3 \pm 0.1$ & $0.4 \pm 0.2$ \\
\hline $20: 5 n-3$ & $7.8 \pm 2.3$ & 9.8 & $5.8 \pm 0.4$ & $3.4 \pm 0.9$ & 8.8 & $2.9 \pm 0.5$ & $3.7 \pm 1.1$ \\
\hline $22: 1 n-11$ & $9.3 \pm 8.4$ & 2.1 & $2.4 \pm 0.0$ & $5.5 \pm 2.7$ & 2.7 & $3.3 \pm 0.6$ & $12.3 \pm 4.9$ \\
\hline $22: 5 n-3$ & $1.2 \pm 0.4$ & 3.0 & $0.9 \pm 0.0$ & $1.8 \pm 0.5$ & 3.2 & $1.5 \pm 0.1$ & $2.5 \pm 0.3$ \\
\hline $22: 6 n-3$ & $25.6 \pm 12.2$ & 9.9 & $5.9 \pm 0.0$ & $9.6 \pm 1.6$ & 9.9 & $4.2 \pm 0.4$ & $8.9 \pm 2.4$ \\
\hline SAT & $25.8 \pm 0.9$ & 30.2 & $20.3 \pm 0.4$ & $29.9 \pm 3.2$ & 28.6 & $20.1 \pm 1.0$ & $20.4 \pm 3.9$ \\
\hline MONO & $33.0 \pm 13.2$ & 35.6 & $46.5 \pm 0.7$ & $48.3 \pm 3.5$ & 38.4 & $51.9 \pm 1.7$ & $58.0 \pm 8.1$ \\
\hline PUFA & $41.2 \pm 13.2$ & 34.2 & $33.3 \pm 0.6$ & $21.8 \pm 3.1$ & 33.0 & $27.2 \pm 1.3$ & $21.5 \pm 4.5$ \\
\hline n-3 PUFA & $37.6 \pm 12.8$ & 26.2 & $20.3 \pm 0.5$ & $17.6 \pm 2.4$ & 25.3 & $13.5 \pm 1.2$ & $18.2 \pm 3.9$ \\
\hline n-6 PUFA & $3.5 \pm 0.5$ & 7.8 & $13.0 \pm 0.1$ & $4.0 \pm 1.1$ & 7.5 & $13.3 \pm 0.4$ & $3.3 \pm 0.7$ \\
\hline$n-3 / n-6$ & $10.7 \pm 2.5$ & 3.3 & $1.6 \pm 0.1$ & $4.7 \pm 1.3$ & 3.4 & $1.0 \pm 0.0$ & $5.6 \pm 0.6$ \\
\hline
\end{tabular}

vs. $2.7 \pm 0.1 \mathrm{~kg})$, and had a significantly lower condition factor $(0.93 \pm 0.08$ vs. $1.30 \pm 0.02)$ than the other fish recaptured in Masfjord and used for fatty acid analysis during the same period (Weeks 15 to 22) $(\mathrm{p}<0.05$, Student's $t$-tests).

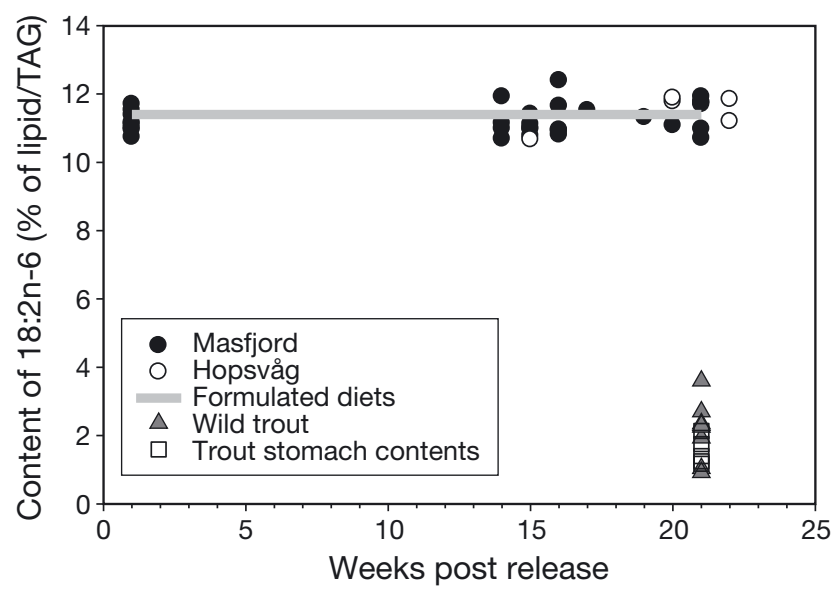

Fig. 5. Contents of $18: 2 n-6$ (\% of fatty acids) in commercial feeds (grey line) and Atlantic salmon Salmo salar muscle (Masfjord: $(\bullet), \mathrm{n}=33$; Hopsvåg: $\mathrm{O}, \mathrm{n}=5$ ) triacylglycerols (TAG) from 1 to $22 \mathrm{wk}$ post release. Levels of 18:2n-6 were also assessed in wild brown trout Salmo trutta tissue (muscle TAG: $\Delta, \mathrm{n}=8$ ) and stomach content (total lipid: $\square, \mathrm{n}=6$ ) in March 2010
The muscle TAG of the 6 recaptured multi-seawinter salmon returning from sea during summer/ autumn 2010 were dominated by $16: 0,18: 1 \mathrm{n}-9,20: 1 \mathrm{n}-9$, $22: 1 \mathrm{n}-11$ and relatively moderate levels of $20: 5 \mathrm{n}-3$ $(3.7 \%)$ and $22: 6 \mathrm{n}-3(8.9 \%)$. However, regardless of other fatty acids, the level of 18:2n-6 averaged $1.6 \%$ and was never higher than $2 \%$ in any fish (Table 2 ).

\section{DISCUSSION}

The present study is the first to use fish fatty acid composition to demonstrate that parts of an escaped salmon population remain in the proximity of the fish farm for a prolonged period, feeding and growing on surplus pellets.

The muscle TAG fatty acid composition agrees with the general observations of stomach filling strongly indicating that, once remaining fish started to feed on commercial diets, they continued to do so over the next 20 wk. For all analyzed fish, the level of 18:2n-6 was very similar to that of the diets indicating that recaptured fish did not feed to any major extent on other prey animals. If they had done so, there would have been a significant decrease in the level of 18:2n-6. As both brown trout, cod and their prey (gut filling) had a 
level of $18: 2 n-6$ of around $2 \%$ of the fatty acids, it is likely that this would have been the level approached by escaped salmon feeding on wild prey. This argument is supported by the low level of $18: 2 n-6(<2 \%)$ in the recaptured sea-ranched salmon that had fed on wild prey. This $2 \%$ level is also in agreement with previous reports for sea-ranched Atlantic salmon off Iceland (Jonsson et al. 1997) suggesting that this is a 'normal' range in northern waters. How fast a change in fatty acid pattern would occur is not possible to establish with certainty. However, a controlled study by Bell et al. (2003) showed that salmon muscle 18:2n-6 will be reduced from $12 \%$ to $6 \%$ in $4 \mathrm{wk}$, and to $4 \%$ within 8 wk when switched from a 'vegetable' diet to a pure marine oil diet. Thus, growing fish captured after 3 mo feeding exclusively on natural marine prey would be expected to have around $4 \% 18: 2 n-6$ or less in muscle TAG. This was not the case in the present study.

Furthermore, those fish caught in Hopsvåg had a very slow growth rate, and were in poor condition indicating that they were probably starving. These also had a level of 18:2n-6 similar to that of the original formulated diets. Starvation leads to consumption of interal lipids and alters many aspects of lipid metabolism; however, the proportion of many fatty acids including 18:2n-6 remains in similar proportions throughout the period of starvation (Johansson \& Kiessling 1991). It can therefore be concluded that these fish had not consumed large amounts of prey animals following release.

The dispersal rate and the probability of displaying cage-feeding behavior were strongly influenced by the time of the year and/or the size of the fish. The smolts and post-smolts released in May and June left the fjord within a few days. The proportion of fish apparently remaining in the fjord the following winter (reflected by a high recapture rate) increased sharply from the August to the October release (Skilbrei 2010). The reduced number of recaptures the following spring indicate that fish had exited the fjord at that time. According to Hansen \& Jonsson (1989) who released salmon from sea-cages at different times of the year, migratory behaviour may not develop exclusively at the smolt stage, but also in adults during the second spring in seawater.

The present study clearly shows that escaped salmon remaining in the fjord over the winter do feed on commercial diets. Feeding preferences of fish that migrated or dispersed out of the fjord could however not be established. Analyses of the stomach content of escaped farmed salmon have given variable results depending on locality of the sampling. Morton \& Volpe (2002) found identifiable stomach content in $\sim 4 \%$ of salmon recaptured in the coastal waters off British Columbia. Hislop \& Webb (1992) distinguished escaped farmed from wild salmon in the catch of a coastal salmon fishery on the west coast of Scotland and found that $35 \%$ of the farmed fish had switched to natural prey, while $65 \%$ had empty stomachs. Experimental fishing in salmon farming regions in Chile revealed that $\sim 60 \%$ of the recaptured salmon had empty stomachs, while $\sim 16 \%$ fed on pellets (Soto et al. 2001). Jacobsen \& Hansen (2001) found a considerable proportion of empty stomachs in salmon caught during autumn $(47 \%)$ and winter $(22 \%)$ in the Northeast Atlantic, but there were no differences between escaped farmed and wild salmon. The probability that an escaped salmon continues to feed on pellets or switches to natural prey may depend on several factors, such as locality of the escape site and season. Fish that have adapted well to life in the wild may be more likely to migrate to the open sea (and vice versa), while a higher proportion of fish staying in coastal areas and fjords may not feed at all, or rely on feed pellets. Such circumstances may help to explain why the proportion of pellet-feeding fish was very high in the present study; they were released from a small narrow fjord at a time of the year when migratory performance was low (Skilbrei 2010), and recaptures were only reported in the vicinity of the release site. Escaped salmon may remain longer in the proximity of the fish farm within a small fjord compared to a more rapid dispersal observed from release sites in a large fjord or exposed locality (Hansen 2006, Whoriskey et al. 2006, Hansen \& Youngsson 2010, Skilbrei et al. 2010). One may anticipate that the proportion of pellet-feeders may be lower if fish escape from more exposed localities, which is much more common in Norwegian aquaculture. However, adult salmon moved within the basin of a large fjord for several months (Skilbrei \& Jørgensen 2010, Skilbrei et al. 2010), and should have had the opportunities to feed on pellets at other farms than their natal farm. Further studies from different types of localities seem to be necessary to get a more detailed picture of the foraging behaviour of escaped salmon. There are no data to show that escaped farmed salmon compete with wild salmon in the open sea (Jonsson \& Jonsson 2006). The present study indicates that competition for prey with wild fish in fjord and coastal areas is not to be expected following escapes during autumn.

The pellet-feeding activity has several implications for the interactions between fish farms and the environment. There is an increased risk of spreading fish diseases which adds to the risks associated with marine fish aggregating around fish farms (Dempster et al. 2009, Uglem et al. 2009). The close contact between the cultured and escaped salmon implies that horizontally transferred diseases such as pancreas disease may spread more easily than previously anticipated (Kristoffersen et al. 2009). Escaped farmed sal- 
mon that feed and grow on surplus pellets during winter also have an increased probability of survival and reproduction, especially if they escape at a time when the conditions are poor in open sea. This is supported by the poor condition of the fish caught in Hopsvågen, which resided farther away from the fish farms and were obviously starved.

\section{CONCLUSIONS}

A high proportion of the fish released in late autumn was recaptured, and grew well, in the proximity of the fish farm during the following winter. Of the fish analyzed, it is unlikely that any had switched to exclusively wild prey diets. Most likely, all fish were feeding predominantly on formulated feed until the time of recapture. Some fish that were recaptured in a small fjord arm did not seem to feed at all. This may indicate that at least some escaped Atlantic salmon do not change to wild prey within 5 mo of escape. Whether this is a feeding behavior that will lead to high mortalities and increased risk of becoming preyed upon remains to be elucidated.

\section{LITERATURE CITED}

Anon (2010) The status of Norwegian salmon stocks in 2010. Report no. 2 from the Norwegian Scientific Advisory Committee for Atlantic Salmon Management (www. vitenskapsradet.no)

Baarøy V, Gjerde B, Heggberget TG, Jensen PE and others (2004) Identifisering av rømt oppdrettslaks. Utredning fra utvalg nedsatt av Fiskeridirektøren [Identification of escaped farmed salmon. Report from committee to the Director of Fisheries]. Fiskeridirektoratet, Bergen

Bell JG, McGhee F, Campbell PJ, Sargent JR (2003) Rapeseed oil as an alternative to marine fish oil in diets of post-smolt Atlantic salmon (Salmo salar): changes in flesh fatty acid composition and effectiveness of subsequent fish oil 'wash out'. Aquaculture 218:515-528

Christie WW (1982) The preparation of derivatives of lipids. In: Christie WW (ed) Lipid analysis. Isolation, separation, identification and structural analysis of lipids, 2nd edn. Pergamon Press, Oxford, p 51-62

Dempster T, Uglem I, Sanchez-Jerez P, Fernandez-Jover D, Bayle-Sempere J, Nilsen R, Bjørn PA (2009) Coastal salmon farms attract large and persistent aggregations of wild fish: an ecosystem effect. Mar Ecol Prog Ser 385:1-14

Ferguson A, Fleming I, Hindar K, Skaala Ø, McGinnity P, Cross TF, Prodöhl P (2007) Farm escapes. In: Verspoor E, Stradmeyer L, Nielsen JL (eds) The Atlantic salmon: genetics, conservation and management. Blackwell Science, Oxford, p 357-398

Fernandez-Jover D, Jimenez JAL, Sanchez-Jerez P, BayleSempere J, Casalduero FG, Lopez FJM, Dempster T (2007) Changes in body condition and fatty acid composition of wild Mediterranean horse mackerel (Trachurus mediterraneus Steindachner 1868) associated to sea cage fish farms. Mar Environ Res 63:1-18

Folch J, Lees M, Sloane-Stanley GH (1957) A simple method for the isolation and purification of total lipids from animal tissues. J Biol Chem 226:497-509

Ford JS, Myers RA (2008) A global assessment of salmon aquaculture impacts on wild salmonids. PLoS Biol 6:e33

Fraser DJ, Houde ALS, Debes PV, O'Reilly P, Eddington JD, Hutchings JA (2010) Consequences of farmed-wild hybridization across divergent wild populations and multiple traits in salmon. Ecol Appl 20:935-953

> Hansen LP (2006) Migration and survival of farmed Atlantic salmon (Salmo salar L.) released from 2 Norwegian fish farms. ICES J Mar Sci 63:1211-1217

> Hansen LP, Jonsson B (1989) Salmon ranching experiments in the river Imsa: effect of timing of Atlantic salmon (Salmo salar) smolt migration on survival to adults. Aquaculture 82:367-373

> Hansen LP, Youngsson AF (2010) Dispersal of large farmed Atlantic salmon, Salmo salar, from simulated escapes at fish farms in Norway and Scotland. Fish Manag Ecol 17: $28-32$

Henderson RJ, Tocher DR (1987) The lipid composition and biochemistry of freshwater fish. Prog Lipid Res 26:281-347

> Heuch PA, Mo TA (2001) A model of salmon louse production in Norway: effects of increasing salmon production and public management measures. Dis Aquat Org 45:145-152

$>$ Hindar K, Fleming IA, McGinnity P, Diserud O (2006) Genetic and ecological effects of salmon farming on wild salmon: modeling from experimental results. ICES J Mar Sci 63: $1234-1247$

Hislop JRG, Webb JH (1992) Escaped farmed Atlantic salmon, Salmo salar L., feeding in Scottish coastal waters. Aquacult Fish Manage 23:721-723

> Jacobsen JA, Hansen LP (2001) Feeding habits of wild and escaped farmed Atlantic salmon, Salmo salar L., in the Northeast Atlantic. ICES J Mar Sci 58:916-933

Jensen O, Dempster T, Thorstad EB, Uglem I, Fredheim A (2010) Escapes of fishes from Norwegian sea-cage aquaculture: causes, consequences and prevention. Aquacult Environ Interact 1:71-83

Johansson L, Kiessling A (1991) Effects of starvation on rainbow trout. Acta Agric Scand 41:201-216

> Jonsson B, Jonsson N (2006) Cultured Atlantic salmon in nature: a review of their ecology and interaction with wild fish. ICES J Mar Sci 63:1162-1181

Jonsson A, Palmadottir H, Kristbergsson K (1997) Fatty acid composition in ocean-ranched Atlantic salmon (Salmo salar). Int J Food Sci Technol 32:547-551

- Kristoffersen AB, Viljugrein H, Kongtorp RT, Brun E, Jansen PA (2009) Risk factors for pancreas disease (PD) outbreaks in farmed Atlantic salmon and rainbow trout in Norway during 2003-2007. Prev Vet Med 90:127-136

Lura H, Sægrov H (1991) Documentation of successful spawning of escaped farmed female Atlantic salmon, Salmo salar, in Norwegian rivers. Aquaculture 98:151-159

McGinnity P, Prodöhl P, Maoiléidigh NÓ, Hynes R and others (2004) Differential lifetime success and performance of native and non-native Atlantic salmon examined under communal natural conditions. J Fish Biol 65(Suppl 1): 173-187

> Megdal PA, Craft NA, Handelman GJ (2009) A simplified method to distinguish farmed (Salmo salar) from wild salmon: fatty acid ratios versus astaxanthin chiral isomers. Lipids 44:569-576

Morton A, Volpe J (2002) A description of escaped farmed Atlantic salmon Salmo salar captures and their characteristics in one Pacific salmon fishery area in British Columbia, Canada, in 2000. Alaska Fish Res Bull 9:102-110. Available at: www.adfg.state.ak.us/pubs/afrb/afrbabst.php 
Naylor R, Hindar K, Fleming IA, Goldburg R, and others (2005) Fugitive salmon: assessing the risks of escaped fish from net-pen aquaculture. Bioscience 55:427-437

Olsen RE, Henderson RJ (1989) The rapid analysis of neutral and polar marine lipids using double-development HPTLC and scanning densitometry. J Exp Mar Biol Ecol 129: 189-197

Skaala Ø, Wennevik V, Glover KA (2006) Evidence of temporal genetic change in wild Atlantic salmon, Salmo salar L., populations affected by farm escapees. ICES J Mar Sci 63:1224-1233

Skilbrei OT (2010) Reduced migratory performance of farmed Atlantic salmon post-smolts from a simulated escape during autumn. Aquacult Environ Interact 1:117-125

Skilbrei OT, Jørgensen T (2010) Recapture of cultured salmon following a large-scale escape experiment. Aquacult Environ Interact 1:107-115

Skilbrei OT, Wennevik V (2006) Survival and growth of searanched Atlantic salmon, Salmo salar L., treated against sea lice prior to release. ICES J Mar Sci 63:1317-1325

Skilbrei OT, Holst JC, Asplin L, Mortensen S (2010) Horizontal movements of simulated escaped farmed Atlantic

Editorial responsibility: Pablo Sánchez-Jerez,

Alicante, Spain salmon (Salmo salar L.) in a western Norwegian fjord. ICES J Mar Sci 67:1206-1215

Skog TE, Hylland K, Torstensen BE, Berntssen MHG (2003) Salmon farming affects the fatty acid composition and taste of wild saithe Pollachius virens L. Aquacult Res 34: 999-1007

Soto D, Jara F, Moreno C (2001) Escaped salmon in the inner seas, southern Chile: facing ecological and social conflicts. Ecol Appl 11:1750-1762

Torstensen BE, Bell JG, Rosenlund G, Henderson RJ, Graff IE, Tocher DR, Sargent JR (2005) Tailoring of Atlantic salmon (Salmo salar L.) flesh lipid composition and sensory quality by replacing fish oil with a vegetable oil blend. J Agric Food Chem 53:10166-10178

Uglem I, Dempster T, Bjørn PA, Sanchez-Jerez P, Økland F (2009) High connectivity of salmon farms revealed by aggregation, residence and repeated movements of wild fish among farms. Mar Ecol Prog Ser 384:251-260

Whoriskey FG, Brooking P, Doucette G, Tinker S, Carr JW (2006) Movements and survival of sonically tagged farmed Atlantic salmon released in Cobscook Bay, Maine, USA. ICES J Mar Sci 63:1218-1223

Submitted: September 20, 2010; Accepted: November 16, 2010 Proofs received from author(s): December 20, 2010 